\title{
Microdeletion syndromes, balanced translocations, and gene mapping
}

\author{
ALBERT SCHINZEL \\ From the Department of Medical Genetics, University of Zürich, Switzerland.
}

SUMmary High resolution prometaphase chromosome banding has allowed the detection of discrete chromosome aberrations which escaped earlier metaphase examinations. Consistent tiny deletions have been detected in some well established malformation syndromes: an interstitial deletion in $15 q 11 / 12$ in the majority of patients with the Prader-Willi syndrome and in a minority of patients with the Angelman (happy puppet) syndrome; a terminal deletion of $17 \mathrm{p} 13.3$ in most patients examined with the Miller-Dieker syndrome; an interstitial deletion of $8 \mathrm{q} 23 \cdot 3 / 24 \cdot 1$ in a large majority of patients with the Giedion-Langer syndrome; an interstitial deletion of $11 \mathrm{p} 13$ in virtually all patients with the WAGR (Wilms' tumour-aniridia-gonadoblastoma-retardation) syndrome; and an interstitial deletion in $22 \mathrm{q} 11$ in about one third of patients with the DiGeorge sequence. In addition, a combination of chromosome prometaphase banding and DNA marker studies has allowed the localisation of the genes for retinoblastoma and for Wilms' tumour and the clarification of both the autosomal recessive nature of the mutation and the possible somatic mutations by which the normal allele can be lost in retina and kidney cells. After a number of $\mathrm{X}$ linked genes had been mapped, discrete deletions in the $\mathrm{X}$ chromosome were detected by prometaphase banding with specific attention paid to the sites of the gene(s) in males who had from one to up to four different $\mathrm{X}$ linked disorders plus mental retardation. Furthermore, the detection of balanced translocations in probands with disorders caused by autosomal dominant or $\mathrm{X}$ linked genes has allowed a better insight into the localisation of these genes. In some females with $\mathrm{X}$ linked disorders, balanced X;autosomal translocations have allowed the localisation of $\mathrm{X}$ linked genes at the breakpoint on the $\mathrm{X}$ chromosome. Balanced autosome;autosome translocations segregating with autosomal dominant conditions have provided some clues to the gene location of these conditions. In two conditions, Greig cephalopolysyndactyly and dominant aniridia, two translocation families with one common breakpoint have allowed quite a confident location of the genes at the common breakpoint at $7 \mathrm{p} 13$ and $11 \mathrm{p} 13$, respectively.

In the first phase of clinical cytogenetics, from the introduction of chromosome analysis into the range of laboratory examinations in 1956 to the late $1960 \mathrm{~s}$, most numerical and a few structural chromosome aberrations were detected through homogenous chromosome staining and autoradiography. The 1970s saw the introduction of banding techniques into cytogenetics and led to the discovery of a large number of different aberrations: interstitial and terminal deletions and duplications and any combination of these (double deletion, deletionduplication, double duplication). Although this phase is not yet over, we entered a third stage in clinical cytogenetics in the early 1980s, the phase of

Received for publication 19 November 1987

Revised version accepted for publication 30 November 1987. prometaphase staining and the combination of cytogenetic and molecular biological methods for the identification of microdeletions and for gene mapping. Among other successes, the combination of cytogenetic and molecular biological methods has already enabled the identification and cloning of a number of oncogenes, but these will not be the subject of this article.

\section{Microdeletion syndromes}

Features common to the syndromes discussed below are: (1) their clinical patterns were already recognised long before their aetiology or probable aetiology, a discrete deletion, became apparent, and (2) some of them were first detected from cytogenetically unusual cases, that is, those with a more complex 
rearrangement and not a simple deletion. Several cases with complex aberrations, always in the same segment of one of the chromosomes involved, led to the hypothesis that a simple deletion of that segment was the cause of all (or at least a large proportion of) cases with this clinical pattern, and this was confirmed by a more careful search for the particular deletion in banded prometaphase preparations. This was the way the deletions in the Prader-Willi syndrome (PWS), Miller-Dieker syndrome (MDS), and DiGeorge sequence (DGS) were detected.

\section{PRADER-WILLI SYNDROME}

This syndrome was first described in nine patients by Prader et $a l^{1}$ in 1956. Cardinal features include diminished fetal and postnatal motor activity with initially absent sucking and swallowing reflexes, necessitating tube feeding during the first few months of life; in boys, hypoplasia of the external genitalia; small hands and feet with short, tapering fingers; short stature; severe to profound psychomotor retardation; seizures; and (often excessive) obesity with onset after the first year of life. The face is marked by the sequelae of muscular hypotonia: narrow forehead with frontal upsweep, upward slanting palpebral fissures, strabismus, and downturned corners of the mouth. Spontaneous puberty is diminished or lacking, and in a significant proportion of patients diabetes sets in around puberty. Life expectancy is grossly diminished (mean about 25 to 30 years). The syndrome usually occurs sporadically. Expression of its clinical components is quite variable and thus classification in patients with incomplete patterns often remains tentative.

\section{Cytogenetics}

The first case with a seemingly balanced $D ; D$ translocation was detected by Bühler $e t a l^{2}$ as early as in 1963. However, a number of further reports dealing with cases with translocations all involving the centromeric region of a chromosome 15 had to appear before Ledbetter et $a l^{3}$ put forward the hypothesis of a microdeletion in $15 q 11 / 12$ as the cause, or one of them, of PWS. This was based on the observation that in all these translocation cases the short arm, centromere, and most proximal long arm of a chromosome 15 was lost. Of these three regions, only the last is known to contain coding DNA sequences. Loss of the centromere and short arm is known, from carriers of Robertsonian translocations, not to alter the phenotype except for reproductive failure. Ledbetter $e t$ al ${ }^{3}$ studied prometaphase preparations from some 40 patients and an equal number of controls for microdeletions of $15 q 11 / 12$. They were able to detect interstitial deletions of this region in about a half of the PWS patients, but in none of the blindly investigated controls (figure). Their results were confirmed in a number of subsequent serial investigations and many single reports (table 1 ). ${ }^{3-9}$ About 50 to $80 \%$ of PWS patients show an aberration of chromosome 15 ; almost $90 \%$ of these are 'simple', deletions, almost $10 \%$ are unbalanced translocations mostly involving, apart from one 15 , another acrocentric or the short arm of a chromosome 9 and leading to loss of 15 pter $\rightarrow \mathrm{q} 11 / 12$, and the remainder include mosaics for deletions, additional small marker chromosomes, and, rarely, other aberrations. If the patients are clinically subclassified according to completeness of the pattern of abnormalities, the deletion is more frequent (about $80 \%$ ) in full blown PWS patients than in cases with an incomplete or abortive pattern of the PWS features.

In two of the rare instances of PWS in sibs or first cousins, balanced translocations were found in one of the parents leading, through unbalanced segregation, to a deletion of $15 \mathrm{pter} \rightarrow \mathrm{q} 11 / 12$ in the patients. ${ }^{1011}$ Less easy to explain is the observation of apparently the same rearrangement in a PWS child and in his healthy parent (translocation, ${ }^{12-14}$ inversion ${ }^{15}$ ). The most likely explanation is an invisible unbalanced recombination at meiosis which led to loss of a submicroscopic segment in the proband.

Application of molecular probes to the diagnosis of interstitial deletions in proximal $15 q$ might become possible in the near future. Donlon et al ${ }^{16}$ reported a patient with a visible deletion of $15 q 11 / 12$ who was hemizygous for four polymorphic DNA segments localised at $15 \mathrm{q} 11 \cdot 2$. There was, in addition, from molecular biological examinations, suspicion of a cytogenetically invisible paracentric inversion. In a second patient with characteristic findings of PWS there was no detectable deletion either cytogenetically or by determination of molecular probes. It would, of course, be interesting to find patients with no visible deletions who are

TABLE 1 Results of series of cytogenetic examinations in patients with the Prader-Willi syndrome.

\begin{tabular}{llllll}
\hline $\begin{array}{l}\text { Reference } \\
\text { examined }\end{array}$ & $\begin{array}{l}\text { No of patients } \\
\text { exormal }\end{array}$ & $\begin{array}{l}\text { De novo } \\
\text { karyotype }\end{array}$ & $\begin{array}{l}\text { De novo } \\
\text { translocation }\end{array}$ & mar+ \\
\hline 3 & 45 & 21 & 23 & 1 & 1 \\
4 & 17 & 9 & 8 & - & - \\
5 & 12 & 0 & 10 & 1 & - \\
6 & 15 & 5 & 9 & 1 & - \\
7 & 16 & 6 & 10 & - & - \\
8.1 & 12 & 0 & 11 & 1 & - \\
8. II & 9 & 4 & 4 & 1 & - \\
9 & 39 & 18 & 21 & - & 1 \\
$3-9$ & 165 & 63 & 96 & 5 & 1 \\
$\%$ & 100 & 38 & 58 & 3 & - \\
\hline
\end{tabular}



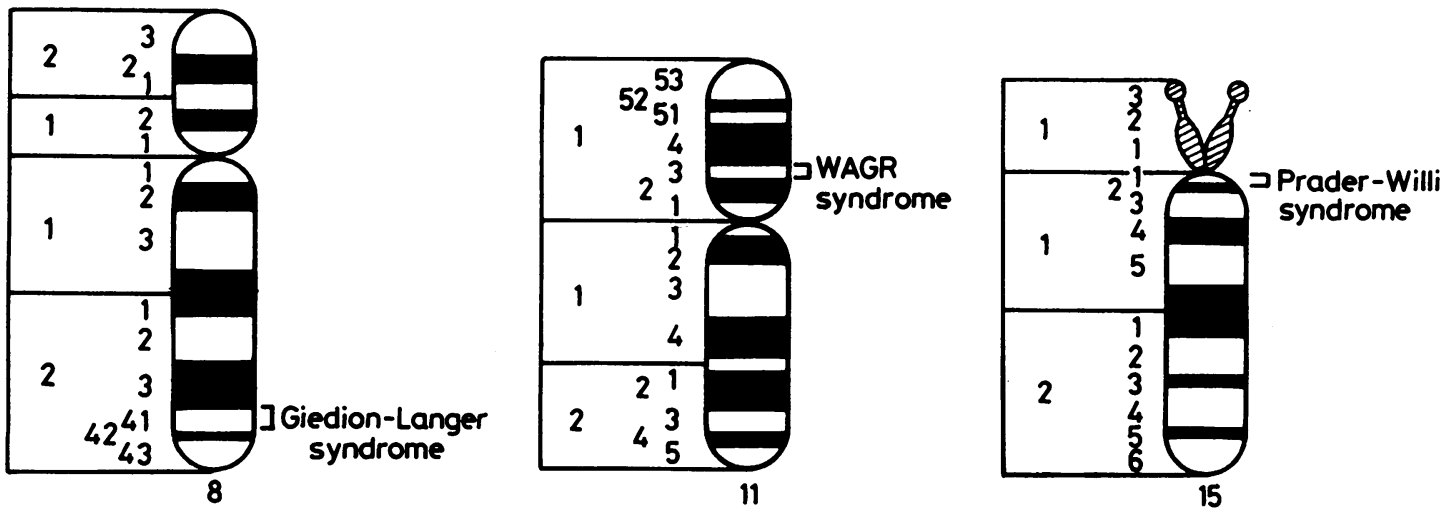

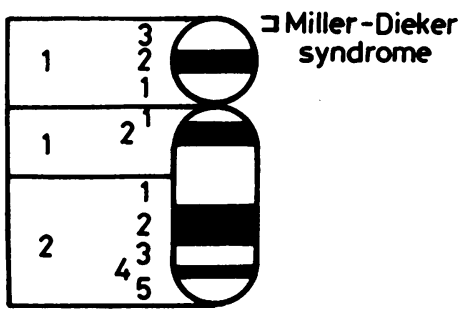

17

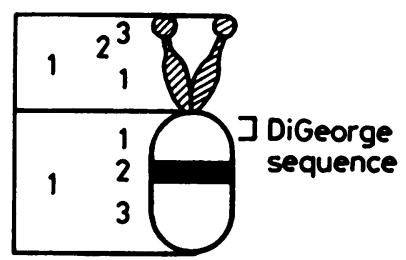

22

FIGURE Schematic representation of banding patterns of chromosomes $8,11,15,17$, and 22 with breakpoints indicated for the six microdeletion syndromes (for AS identical to PWS).

hemizygous for at least one of the four DNA polymorphisms available at present or for further probes in $15 q 11 / 12$ to be determined.

\section{Prenatal diagnosis of PWS?}

Fortunately, virtually all PWS cases are sporadic. However, in view of possible gonadal mosaicism, and according to the usual recommendations, prenatal cytogenetic diagnosis should be offered to any mother after the birth of a child with a numerical or structural chromosome aberration. For the detection of a very subtle interstitial deletion of $15 q 11 / 12$, this is a very difficult task: in contrast to blood chromosome examinations, preparations from chorionic villi or cultured amniotic fluid cells are qualitatively inferior, the time for examination is limited, and there is no possibility of repeating the procedure. Thus, such an examination for a simple deletion is not recommended. Alternative measures could be the ultrasonographic investigation of fetal motor activity and, in future, determination of DNA probes within the deleted segment. ${ }^{17}$

MILLER-DIEKER SYNDROME (MDS)

This syndrome was first described by Miller ${ }^{18}$ in 1963 and later by Dieker et al ${ }^{19}$ in 1969 and is one of the few clinical syndromes featuring lissencephaly (pachygyria, incomplete or absent gyration of the cerebrum). The pattern of abnormalities also includes microcephaly, wrinkled skin over the glabella and frontal suture, prominent occiput, narrow forehead, downward slanting palpebral fissures, small nose and chin, cardiac malformations, hypoplastic male external genitalia, growth retardation, and profound mental deficiency with seizures and EEG abnormalities. Life expectancy is grossly reduced, with death mostly occurring during early childhood. Several observations of affected sibs have suggested autosomal recessive inheritance.

\section{CYTOGENETICS}

MDS is caused by a tiny terminal deletion of $17 p$ involving 17p13.3 (figure). As the deleted segment is very small and the banding pattern of $17 p$ not very distinctive, unbalanced translocations with a $17 p+$ chromosome owing to duplication-deletion were the first to be detected. ${ }^{20}$ These few translocation families with more than one affected member had earlier led the authors to suggest autosomal recessive inheritance. ${ }^{21}$ About 15 families with 27 patients have so far been cytogenetically investigated with special attention paid to $17 \mathrm{p}^{22}$ In seven 
families, an unbalanced familial translocation was found in the patient(s), and two sibs of a further family had an unbalanced inversion. ${ }^{23}$ Patients with additional duplications of autosomal segments showed, besides the MDS phenotype, features caused by duplication of another autosomal segment. Two patients had ring chromosome 17 and three had simple de novo deletions. In only two patients was no aberration found. As simple deletions generally form the major cytogenetic subgroup of patients with a chromosome deletion syndrome, the small proportion of simple deletions in MDS suggests that these are mostly still overlooked because of the small size and the indistinct banding pattern of $17 \mathrm{p} 13 \cdot 3$. Thus, molecular probes in $17 \mathrm{p} 13$ would greatly facilitate the diagnosis in patients with MDS.

\section{GIEDION-LANGER SYNDROME (GLS)}

The first descriptions were by Giedion ${ }^{24}$ and Langer $^{25}$ in 1969. Cardinal features include multiple cone shaped epiphyses; multiple cartilagineous exostoses; microcephaly with (mostly mild) mental deficiency; sparse scalp hair with early balding; multiple naevi; and a pattern of facial dysmorphism (bulbous nasal tip, thickened alar cartilage, upturned nares, prominent philtrum, thin lips, large protruding ears). Most cases occur sporadically. Life expectancy is only mildly limited.

\section{Cytogenetics}

Bühler $e t a l^{26}$ and Pfeiffer $^{27}$ first reported patients with deletions within the long arm of chromosome 8 . The two authors, however, localised the deleted segment in different bands: Bühler assumed a terminal deletion of $8 \mathrm{q} 24$ while Pfeiffer described an interstitial deletion of $8 \mathrm{q} 21$. Subsequently, more than a dozen further cases with $8 \mathrm{q}$ deletions were detected, and nowadays most investigators agree that the deletion causing GLS involves at least $8 \mathrm{q} 23 \cdot 3$ and $8 \mathrm{q} 24 \cdot 1^{28-32}$ (figure). A proportion of the patients had additional atypical findings, for example, coloboma of the iris, microphthalmia, syndactyly, cardiac defects, caudal regression, and hypoplasia of the tibia. It is likely that the deletions in different patients are different in size and extent towards the centromere and telomere, thus leading to varying additional malformations. However, the cardinal features are probably caused by a deletion of always the same segment, $8 \mathrm{q} 23 \cdot 2 \rightarrow \mathrm{q} 24 \cdot 1$. In a minority of patients with GLS, even in prometaphase preparations of excellent quality, no deletion in $8 \mathrm{q}$ can be found. These latter patients are less severely mentally retarded and they less frequently have additional malformations than those with visible deletions. The minimal pathognomonic seg- ment for the manifestation of the cardinal features of GLS is probably too small to be detected by present prometaphase banding. Again, DNA polymorphisms within the pathognomonic segment would facilitate the diagnosis in patients with GLS.

WILMS'TUMOUR-ANIRIDIA-GONADOBLASTOMAMENTAL RETARDATION SYNDROME (WAGRS)

About three dozen patients with similar deletions have been reported. ${ }^{33-35}$ Clinical findings of the syndrome, which was first recognised almost 100 years ago, include aniridia, hypernephroma (Wilms' tumour), male genital hypoplasia of varying degree up to pseudohermaphroditism (bifid scrotum, small penis with hypospadias, cryptorchidism), gonadoblastoma, mental deficiency, and a pattern of facial dysmorphism (long face, upward slanting palpebral fissures, ptosis of upper lids, blepharophimosis, beaked nose, and low set, poorly formed auricles). Aniridia or iris hypoplasia constitutes the most consistent finding and is often associated with corneal clouding, cataract, defects of the anterior chamber, glaucoma, and optic atrophy. All patients are virtually blind. Aniridia is not confined to this chromosome aberration and it can also be a feature of various other aberrations including trisomy 13 . Hypernephroma and gonadoblastoma manifest themselves in about a quarter to a third of patients with the syndrome and are, after the cardiac malformations, the second most frequent cause of reduced survival.

CYTOGENETICS

Andresen $e t a l^{36}$ and Riccardi $e t a l^{37}$ first reported interstitial deletions in $11 \mathrm{p}$ in patients with the WAGRS in 1978. Subsequently, about three dozen further patients with similar deletions were found, ${ }^{33-35}$ and it turned out that the deletion always included band $11 \mathrm{p} 13$ or parts of it. The size of the deleted segment varies between individual patients and correlates well with the extent of the malformations and mental deficiency. The major cytogenetic subgroup includes patients with simple de novo deletions; rarer are de novo unbalanced translocations, ${ }^{38}{ }^{39}$ and familial insertional translocations are occasionally found. ${ }^{40-42}$ A pair of monozygous twins were concordant for aniridia, but discordant for hypernephroma ${ }^{43}$ Since the gene coding for the enzyme catalase (CAT) is also localised in 11p13 and is deleted in almost all WAGRS patients (serum enzyme activity reduced to about $50 \%$ of normal), CAT determination can be helpful for the detection of submicroscopic deletions.

(For the dominantly inherited aniridia segregating with balanced translocations and for Wilms' tumour see below.) 
DIGEORGE SEQUENCE (DGS)

The DiGeorge sequence is a localised defect of development and therefore not a syndrome. It can occur as an isolated defect or as a component of a variety of syndromes. The defect affects the development of the third and fourth pharyngeal pouches and the fourth branchial arch and their derivatives and therefore the following structures: thymus and parathyroid gland (hypoplasia or agenesis), external ear (low position, hypoplasia of auricle, atresia of external auditory canal), aortic arch (duplication as well as interruption, abnormal insertion of vessels), and heart (ventricular septal defect and others). Clinical manifestations after birth include cardiac failure, tetanic seizures, and proneness to infections, particularly of the respiratory system. Heart defects are often lethal. Patients with the chromosome aberration described below also often display facial dysmorphism, especially hypertelorism, downward slanting palpebral fissures, small and low set ears, and small mandible.

\section{Cytogenetics}

While most malformations and malformation sequences can be associated with a large number of chromosome aberrations, the DiGeorge sequence is mainly found in one particular deletion, that is, deletion of a segment within 22q11 (figure). A second, less frequently associated, aberration is terminal deletion of $10 \mathrm{p}$. De la Chapelle et $a l^{44}$ reported five members of a family with DGS who died shortly after birth; in three of them, unbalanced segregation of a familial 20;22 translocation had led to duplication of $20 \mathrm{p}$ and deletion of $22 \mathrm{pter} \rightarrow \mathrm{q} 11$, and in the other two patients, who were not cytogenetically investigated, one parent was a balanced translocation carrier. As DGS is not a feature of duplication of $20 \mathrm{p}$ without concomitant deletion of parts of 22,45 and as, like chromosome 15 in PWS, deletion of the centromere and short arm of 22 is known not to affect the phenotype, the authors concluded that deletion of a small segment proximally in $22 \mathrm{q}$ must be responsible for the DGS in their patients. As with the chromosome 15 aberration in PWS, the deletion is easily visible in unbalanced translocations, whereas no patient with a simple deletion has so far been found.

The findings in three patients of a family reported by Greenberg et $a l^{46}$ show the variable clinical manifestations caused by presumably the same deletion: a mother and one of her children carried an unbalanced $4 ; 22$ translocation leading to loss of 22 pter $\rightarrow$ q11. The proband displayed a pattern of facial dysmorphism, a heart defect, partial hypoparathyroidism, thymus dysfunction, and retarded mental development. The mother was much more mildly affected, displaying only mild mental retardation and a partial $\mathrm{T}$ cell defect, but no other $\stackrel{\vec{S}}{\rightarrow}$ malformations. Two older sibs of the proband hado died of cardiac malformations without chromosome $\overline{0}$ studies; the only necropsied sib had agenesis of the $\frac{\bar{c}}{\frac{1}{\sigma}}$ thymus, hypoplasia of the parathyroid glands, and $\stackrel{\varnothing}{\varrho}$ truncus arteriosus communis. Further reports came from Kelley et al, ${ }^{47}$ Augusseau et al, ${ }^{48}$ and Faed et ${ }^{\infty}$ $a l .{ }^{49} \mathrm{~A}$ search for DNA polymorphisms within the $\vec{\circ}$ critical segment deleted in DGS patients has not yet $\overrightarrow{\vec{\omega}}$ been successful. However, Cannizzaro and $\stackrel{\omega}{\omega}$ Emanuel $^{50}$ showed that the distal breakpoint in $22 \mathrm{q} 11$ in cases with DGS is proximal to the breakpoint in chronic myelogenous leukaemia, but $\mathrm{N}$ not proximal to the breakpoint in Burkitt's lym- $v$ phoma with $8 ; 22$ translocation.

ANGELMAN (HAPPY PUPPET) SYNDROME (AS)

The syndrome was first described by Angelman in 1965 and the patients were called 'puppet children' because of a jerky, ataxic gait. ${ }^{51}$ Consistent features $\vec{\bullet}$ include severe mental retardation, absence of $\mathscr{\infty}^{\circ}$ speech, seizure disorder, easily provoked or unprovoked paroxysms of laughter, hypotonia, microbrachycephaly, vertical inclination of skull base, occipital furrow, fair hair, ocular abnormalities, 긍 midface hypoplasia, macrostomia and widely spaced teeth, tongue protrusion with drooling, and $\underset{\complement}{\mathbb{Q}}$ prognathism. Some 50 cases have been reported $\overrightarrow{\vec{A}}$ including four instances of affected sibs, but the $\frac{0}{3}$ syndrome is probably much more frequent than this low number reflects. ${ }^{52}$

\section{Cytogenetics}

Very recently, three independent investigators reported interstitial deletions of proximal $15 \mathrm{q}$ in AS patients, comprising the same segment which is $\delta$ deleted in a proportion of PWS patients. In the first American paper, one out of two patients investi- 윽 gated had a deletion of $15 \mathrm{q} 11 \cdot 2,{ }^{53}$ in the second, two patients had a deletion of $15 \mathrm{q} 11 \rightarrow \mathrm{q} 13,53 \mathrm{a}$ 음 and in a British study, four out of 10 patients showed $\frac{\bar{N}}{\mathrm{~N}}$ a similar deletion. ${ }^{54}$ In the latter investigation, there $\mathcal{O}$ was one further patient with a seemingly balanced $N$ pericentric inversion, inv(15)(p11q13), which was స్ట also present in the healthy mother. This observation parallels one of a familial inversion in a PWS child. ${ }^{15}<$ Out of 95 controls, consecutive cytogenetic refer- $\frac{C}{\square}$

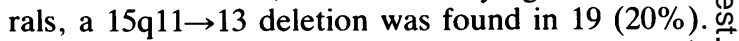
At present, these findings and the cytogenetic 0 similarity of aberrations in two clinically distinct ${ }_{0}^{-}$ syndromes is difficult to understand. It can be $\underset{\mathbb{Q}}{\mathbb{Q}}$ expected, however, that series of patients with AS will be examined in due course, and that molecular $\frac{\varrho}{\sigma}$ probes from proximal $15 q$ will soon be available and be applied to such examinations. 


\section{Childhood tumours}

Retinoblastoma (Rb) and hypernephroma (Wilms' tumour, WT), two malignant tumours of early infancy, are both sometimes found in patients with malformation syndromes. The association of retinoblastoma in combination with multiple congenital defects with (interstitial) deletion of the long arm of chromosome 13 was first described in the prebanding era. ${ }^{55}$ After banding methods had been applied in the examination of various cases, it turned out that, although the deletions differed in size and extent towards the centromere or telomere or both, a deletion within band $13 \mathrm{q} 14$ was always present. ${ }^{56} \mathrm{~A}$ parallel observation, namely a consistent deletion in $11 \mathrm{p} 13$, was found in all cases of the WAGR syndrome with occurrence of a Wilms' tumour (see above). From these observations the conclusion was drawn that a gene causing the tumour was localised within segment $13 \mathrm{q} 14$ for retinoblastoma and $11 \mathrm{p} 13$ for Wilms' tumour. As a next step, tumour tissue versus somatic tissue from affected patients was examined for markers (esterase D, the gene for which is also localised in 13q14, CAT at 11p13) and later for polymorphic DNA segments. It turned out that, as compared to the somatic cells, the normal allele had, through different pathways, been lost in the tumour cells $\left(\mathrm{Rb},{ }^{57-60} \mathrm{WT}^{61-63}\right)$. This could have happened through loss of the entire chromosome containing the normal allele (non-disjunction leading to hemizygosity), deletion of the normal allele (hemizygosity), non-disjunction and reduplication of the mutant allele (homozygosity), or mitotic recombination (homozygosity). Through the same pathogenetic mechanism, patients carrying the $\mathrm{Rb}$ gene are also prone to osteosarcoma regardless of whether or not they have earlier had retinoblastoma. ${ }^{64}$ It seems that for retinoblastoma the probability is high that one of these steps occurs within the first few years of development in one or more retinal cells which consequently convert to tumour cells: virtually all patients with interstitial deletions including 13q14 develop retinoblastoma, and many pedigrees of carriers of the recessive $R b$ gene resemble dominant pedigrees with incomplete penetrance of about $80 \%$. Incompletely dominant pedigrees are much rarer in Wilms' tumour, although this tumour is not so much rarer in the population (1:20000 for Rb, 1:50000 for WT).

The $\mathrm{Rb}$ gene has recently been cloned, ${ }^{65-67}$ but this has not yet been achieved for the WT gene.

\section{Cytogenetically visible deletions in patients with one or more $\mathrm{X}$ linked disorders}

In the very recent past, since many genes on the $\mathrm{X}$ chromosome have been finely mapped, attempts were made to identify small deletions cytogenetically. The first candidates for such specific prometaphase examinations of just a short $\mathrm{X}$ segment were boys who were affected with more than one $\mathrm{X}$ linked disorder, for one of which at least the gene localisation was known. Two groups of investigators have independently succeeded in showing a very small deletion at $\mathrm{Xp} 21$ in a patient affected with Duchenne muscular dystrophy (DMD), adrenal insufficiency, and glycerol kinase deficiency, ${ }^{6869}$ while no such deletion was visible in two other boys. ${ }^{70}$ One investigator was even able to show, through cytogenetic, DNA, and flow cytometry studies, a (familial) deletion in Xp21 in two cousins who only had DMD and mental retardation. ${ }^{71}$ A deletion in Xq21.1 was observed in a family with affected males with choroideraemia and mental retardation ${ }^{72}$ and in a patient with choroideraemia, deafness, and mental retardation. ${ }^{73}$ Similar investigations are of great importance for further detailed mapping of both disease loci and polymorphic DNA segments.

\section{Gene mapping by translocations}

\section{$X$ LINKED DISORDERS}

The method of mapping a gene by using patients with balanced translocations with common breakpoints was first used for Duchenne muscular dystrophy (DMD) and thereafter for other $\mathrm{X}$ linked diseases. This was not purely by chance. Such mapping is easier for the $\mathrm{X}$ chromosome because one need not discriminate between two possible breakpoints; the one on the $\mathrm{X}$ will be the breakpoint one is looking for and, because of the specific situation of $X$ inactivation, one could select for a small and very specific group of patients: females with an $\mathrm{X}$ linked disorder which otherwise almost exclusively occurs in males. If the breakpoint on the $\mathrm{X}$ chromosome of an $\mathrm{X}$; autosomal translocation runs through, and thus inactivates, an $X$ linked gene, the carrier would theoretically be heterozygous and thus (almost always) healthy and unaffected. However, depending on the $\mathrm{X}$ breakpoint, and possibly also on the size of the autosomal segment attached to the $X$, an $X$;autosomal translocation will alter the normally random $X$ inactivation pattern in such a way that the normal $X$ is mostly or exclusively inactivated. Inactivation of the translocation $X$ chromosome would require that both parts of the $\mathrm{X}$ (only one containing the presumed inactivation centre on proximal $\mathrm{Xq}$ ) are inactivated; in addition, there is the risk of the inactivation spreading to the attached autosomal segment(s) resulting in mosaic inactivation and thus 
in mosaic monosomy of the autosomal segments. For the gene disrupted through the breakpoint on the $X$, the result is that there is no active allele: one is inactivated through interruption, the other constantly inactivated, a situation similar to hemizygosity in affected males. In disorders with limited survival or reproductive fitness or both, such patients always occur sporadically because an inherited translocation could only come from the mother, and she would have to be affected as well. In addition, the majority of $\mathrm{X}$;autosomal translocations in females lead to ovarian failure.

Table 2 presents examples of X;autosomal translocations found in females affected with $\mathrm{X}$ linked disorders. By far the most frequent example is DMD with various translocations always involving $\mathrm{Xp} 21$, but with different autosomal breakpoints; more than two dozen different translocations have been found ${ }^{82}$ In one instance, a similar breakpoint was found in a girl with Becker muscular dystrophy which is now known to be allelic with DMD. ${ }^{81}$ The localisation of different closely linked and intragenic DNA polymorphisms and the recent sequencing of the DMD gene ${ }^{85}$ began with the information of possible gene location at $\mathrm{Xp} 21$ which came from the first DMD females with X;autosomal translocations. In most of the other disorders listed in table 2, the breakpoint was the first information, or an important hint, about gene localisation. The lack of translocation females with haemophilia $A$ and $B$ is striking, especially since $\mathrm{X}$; autosomal translocation carrier females affected with other $\mathrm{X}$ linked diseases, whose mutations are localised in the region $\mathrm{Xq} 25 \rightarrow \mathrm{q} 28$, have been found.

\section{AUTOSOMAL DISORDERS}

The strategy of mapping genes by chromosome analysis of patients with autosomal dominant conditions is based on the hypothesis that a minority of the mutations could be caused by translocations with one breakpoint running through the gene and thus hindering the production of the correct gene pro-

TABLE $2 X$; autosomal translocations in female patients with $X$ linked disorders.

\begin{tabular}{llll}
\hline $\begin{array}{l}\text { McKusick } \\
\text { No }\end{array}$ & Disorder & Breakpoint & Reference \\
\hline 30405 & & & \\
30510 & Aicardi syndrome & Xp22 & 74 \\
30540 & Anhidrotic ectodermal dysplasia & Xq12 & 75 \\
30830 & Aarskog syndrome & Xq13 & 76 \\
30940 & Incontinentia pigmenti & Xp11 & 77 \\
30990 & Menkes syndrome & Xq13 & 78 \\
30900 & Lowe syndrome & Xq26/7 & 79 \\
31010 & BMD & Xq25 & 80 \\
31020 & DMD & Xp21 & 81 \\
31060 & Norrie disease & Xp21 & 82 \\
31430 & Goeminne syndrome & Xp11 & 83 \\
\end{tabular}

duct. In the case of mutations which do not affect reproduction, the translocation should constantly $\stackrel{\oplus}{+}$ segregate together with the disorder. Obviously, at ${ }^{\circ}$ least two independent translocations are required which should have one breakpoint in common in $\frac{\bar{\sigma}}{5}$ order to conclude that the gene could be located at $\stackrel{\Phi}{\varrho}$ that site. This condition has been fulfilled in two disorders, dominant aniridia and Greig cephalopoly- $\vec{a}$

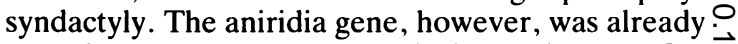
tentatively mapped at $11 \mathrm{p} 13$ from the WAGR $\vec{\omega}$ deletion (see above) before the two families with translocations segregating with aniridia with one $\overline{3}$ breakpoint at $11 \mathrm{p} 13$ in common, but different second breakpoints, were reported. ${ }^{86} 87$ In Greig or cephalopolysyndactyly, a common breakpoint at $v$

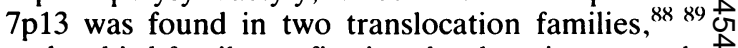
and a third family confirming that location recently 0 came to our notice (Grzeschik, 1987, personal communication). A so far unclassified skeletal $\vec{c}$ dysplasia segregating with a $2 \mathrm{q} 32 ; 8 \mathrm{p} 13$ translocation in a family has been reported. ${ }^{90}$ In this instance, it $\vec{\bullet}$ can be hypothesised that the gene causing this type $\mathscr{\odot}$ of skeletal dysplasia could be localised at one of the two breakpoints. A family in which myotonic dystrophy type Steinert was segregating with a $5 q 23 ; 8 q 23$ translocation shows that such findings have to be regarded with some caution since the gene is known to be localised on chromosome $19 .{ }^{91} \stackrel{\circ}{\complement}$ In another family, a 4;5 translocation segregated $\underset{\overrightarrow{0}}{\vec{\prime}}$ with Huntington's chorea in two generations, but $\frac{3}{3}$ the breakpoint in chromosome 4 was at q21 while the disease locus is at $4 \mathrm{p} 16 .{ }^{92}$

Further autosomal breakpoint mapping through translocation cases and, if a gene does not exclude reproduction, translocation families will require $\dot{0}$ great effort, but will probably allow localisation of some autosomal dominant genes and might possibly give some hints towards gene localisation for recessive disorders.

\section{References}

1 Prader A, Labhart A, Willi H. Ein Syndrom von Adipositas, Kleinwuchs, Kryptorchismus und Oligophrenia nach myoto- $N$ nicartigem Zustand im Neugeborenenalter. Schweiz Med Wochenschr 1956;86:1260-1.

${ }^{2}$ Bühler EM, Rossier R, Bodis I, Vulliet V, Bühleı UK. Stalder N G. Chromosomal translocation in a mentally deficient child with $\omega$ cryptorchidism. Acta Paediatr Scand 1983;52:177-82.

${ }^{3}$ Ledbetter DH, Mascarello JT, Riccardi VM, Harper VD, Airhart SD, Strobel RJ. Chromosome 15 abnormalities and the $\frac{C}{\Phi}$ Prader-Willi syndrome: a follow-up report of 40 cases. $\mathrm{Am} \mathrm{J}$ Hum Genet 1982;34:278-85.

4 Mattei JF, Mattei MG, Giraud F. Prader-Willi syndrome and chromosome 15. Hum Genet 1983;64:356-62.

5 Cassidy SB, Thuline HC, Holm VA. Deletion of chromosome $\stackrel{\mathbb{D}}{\mathrm{Q}}$ 15 (q11-13) in a Prader-Labhart-Willi syndrome clinic popula- $\vec{D}$ tion. Am J Med Genet 1984;17:485-95.

${ }^{6}$ Fear CN, Mutton DE, Berry AC, Heckmatt JZ, Dubowitz V. Chromosome 15 in Prader-Willi syndrome. Dev Med Child Neurol 1985;27:305-11. 
${ }^{7}$ Hasegawa T. Miyata A. Kitazumi E. et al. Cytogenetic studies of young children with acromicria. hypogenitalism and history of severe hypotonia. Ain J Hum Genet 1985:37:57A.

' Niikawa N. Ishikiriyama S. Clinical and cytogenetic studies of the Prader-Willi syndrome: evidence of phenotype-karyotype correlation. Hum Genet 1985;69:22-7.

"Butler MG, Meaney FJ, Palmer CG. Clinical and cytogenetic survey of 39 individuals with Prader-Labhart-Willi syndrome. Am J Med Genet 1986;23:793-809.

1" Hasegawa T. Hara M. Ando M. et al. Cytogenetic studies of familial Prader-Willi syndrome. Hum Genet 1984;65:325-30.

"Fernandez F. Berry C. Mutton D. Prader-Willi syndrome in siblings due to unbalanced translocation between chromosomes 15 and 22. Arch Dis Child 1987:62:841-3.

12 Smith A. Noel M. A girl with the Prader Willi syndrome and Robertsonian translocation 45.XX.t(14:15)(p11;q11) which was present in three normal family members. Hum Genet 1980:55: 271-3.

13 Berry AC. Whittingham AJ. Neville BGR. Chromosome 15 in floppy infants. Arch Dis Child 1981:56:882-5.

it Smith A. Murray R, den Dulk G. Familial delction. Ann Genet (Paris) 1983:26:91-3.

15 Winsor EJT, Welch JP. Prader-Willi syndrome associated with inversion of chromosome 15. Clin Genet 1983:24:456-61.

${ }^{16}$ Donlon TA, Lalande M. Wyman A. Bruns G, Latt SA. Isolation of molecular probes associated with the chromosome 15 instability in the Prader-Willi syndrome. Proc Natl Acad Sci USA 1986:83:4408-12.

17 Schinzel A. Approaches to the prenatal diagnosis of the PraderWilli syndrome. Hum Genet 1986:74:327.

${ }^{1 \times}$ Miller JQ. Lissencephaly in two siblings. Neurology (Minneap) 1963:13:841-50).

19 Dieker H, Edwards RH, ZuRhein G, Chou SM, Hartman HA, Opitz JM. The lissencephaly syndrome. Birth Defects 1969:V(2): 53-64.

20) Dobyns WB, Stratton RF, Parke JT, Greenberg F, Nussbaum RL, Ledbetter DH. Miller-Dieker syndrome: lissencephaly and monosomy 17p. J Pediatr 1983:102:552-8.

2 Stratton RF. Dobyns WB. Airhart SD. Ledbetter DH. New chromosomal syndrome: Miller-Dieker syndrome and monosomy 17p13. Hum Genet 1984:67:193-200).

22 Goutières F. Aicardi J, Rethoré MO. Pricur M, Lejeune J. Syndrome de Miller-Dicker familial et translocation chromosomique (15:17). Arch Fr Pediatr 1987:44:501-4.

${ }_{23}$ Greenberg F. Stratton RF. Lockhart LH. Elder FFB. Dobyns WB. Ledbetter DH. Familial Miller-Dicker syndrome associated with pericentric inversion of chromosome 17. Am J Med Genet 1984:23:853-9.

${ }^{24}$ Giedion A. Dic peripheren Dysostosen-ein Sammelbegriff. Fortschr Röntgenstr 1969:110:507-24.

${ }^{25}$ Langer LO. The thoracic-pelvic-phalangeal dystrophy. Birth Defects 1969:V(4):55-64.

26 Bühler EM, Bühler UK, Stalder GR, Jani L, Jurik LP. Chromosome deletion and multiple cartilagineous exostoses. Eur J Pediatr 1980;133:163-6.

27 Pfeiffer RA. Langer-Giedion syndrome and additional congenital malformations with interstitial deletion of the long arm of chromosome 846.XY.del(8)(q13-q22). Clin Genet 1980;18: 142-6.

${ }^{2 x}$ Fukushima Y, Kuroki Y, Izawa T. Two cases of the LangerGiedion syndrome with the same interstitial deletion of the long arm of chromosome 8: 46,XY or XX.del (8)(q23.3q24.13). Hum Genet 1983:64:90-3.

${ }^{29}$ Bowen P. Biederman B. Hoo JJ. The critical segment for the Langer-Giedion syndrome: 8q24-11-q24-12. Ann Genet (Paris) 1985;28:224-7.

3) Shabtai F, Sandowski U, Nissimov R, Klar D, Halbrecht I. Familial syndrome with some features of the Langer-Giedion syndrome, and paracentric inversion of chromosome 8 , inv 8(q11·23-q21.1). Clin Genet 1985;27:600-5.
31 Goldblatt J. Smart RD. Tricho-rhino-phalangeal syndrome without exostoses, with an interstitial deletion of $8 \mathrm{q} 23$. Clin Genet 1986:29:434-8.

32 Bühler EM, Bühler UK, Beutler C, Fessler R. A final word on the tricho-rhino-phalangeal syndromes. Clin Genet 1987:31: 273-5.

33 Turleau C, de Grouchy J, Tournade MF, Gagnadoux MF, Junien C. Del 11p/aniridia complex. Report of three patients and review of 37 observations from the literature. Clin Genet 1984;26:356-62.

${ }^{34}$ Narahara K, Kikkawa K, Kimira S, et al. Regional mapping of catalase and Wilms tumor-aniridia. genitourinary abnormalities, and mental retardation triad loci to the chromosome segment 11p1305-p1306. Hum Genet 1984;66:181-5.

35 Mochon MC, Blanc JF. Plauchu H, Philip T. Syndrome WAGR, Wilms, aniridie, gonadoblastome, retard mental: revuc générale à propos de deux observations. Pediatrie 1987;42: 249-52.

36 Andresen SR. Geertinger P. Larsen HW, et al. Aniridia, cataract and gonadoblastoma in a mentally retarded girl with deletion of chromosome 11. Ophthalmologica 1978:176:171-7.

37 Riccardi VM, Sujanski E, Smith AC. Francke U. Chromosomal imbalance in the aniridia-Wilms's tumor association: $11 \mathrm{p}$ interstitial deletion. Pediatrics 1978:61:604-10.

${ }^{36}$ Francke U, Holmes LB, Riccardi VM. Aniridia-Wilms's tumor association: evidence for specific deletion of $11 \mathrm{p} 13$. Cytogenet Cell Genet 1979:24:185-92.

${ }^{39}$ Gödde-Salz E, Behnke H. Aniridia, mental retardation and an unbalanced reciprocal translocation of chromosomes 8 and 11 with an interstitial deletion of 11p. Eur J Pediatr 1981;136:93-6.

4) Hittner HM. Riccardi VM. Francke U. Aniridia caused by a heritable chromosome 11 deletion. Ophthalmology 1979;86: 1173-83.

41 Yunis JJ, Ramsay NKS. Familial occurrence of the aniridiaWilms tumor syndrome with deletion $11 \mathrm{p} 13-14 \cdot 1$. J Pediatr 1980;96:1027-30.

${ }^{42}$ Kousseff BG, Agatucci A. Aniridia-Wilms tumor association. J Pediatr 1981;98:676-8.

4. Cotlier E. Rose M, Moel SA. Aniridia, cataracts, and Wilms tumor in monozygotic twins. Am J Ophthalmol 1978;86:129-32.

4 De la Chapelle A, Herva R, Koivisto M. Aula P. A deletion in chromosome 22 can cause DiGeorge syndrome. Hum Genet 1981:57:253-6.

15 Schinzel A. Catalogue of unbalanced chromosome aberrations in man. Berlin, New York: Walter de Gruyter, 1984.

t6 Greenberg F. Crowder WE, Paschall V. Colon-Linares J, Lubianski B, Ledbetter DH. Familial DiGeorge syndrome and associated partial monosomy of chromosome 22. Hum Genet 1984:65:317-9.

47 Kelley RI, Zackai EH, Emanuel BS, Kistenmacher M, Greenberg F, Punnett HH. The association of the DiGeorge anomalad with partial monosomy of chromosome 22. J Pediatr 1982;101: 197-200.

t* Augusseau S, Jouk S, Jalbert P. Prieur M. DiGeorge syndrome and 22q11 rearrangements. Hum Genet 1986;74:206.

${ }^{49}$ Faed MJW, Robertson J, Swanson Beck J, Cater JI, Bose B, Madlom MM. Features of DiGeorge syndrome in a child with 45, XX, -3, -22, $+\operatorname{der}(3), \mathrm{t}(3 ; 22)(\mathrm{p} 25 ; \mathrm{q} 11)$. J Med Genet 1987; 24:225-7.

5) Cannizzaro LA, Emanuel BS. In situ hybridization and translocation breakpoint mapping. III. DiGeorge syndrome with partial monosomy of chromosome 22. Cytogenet Cell Genet 1985:39:179-83.

51 Angelman H. 'Puppet' children: A report of three cases. Dev Med Child Neurol 1965;7:681-8.

52 Willems PJ, Dijkstra I, Brouwer OF, Smit GPA. Recurrence risk in the Angelman ('happy puppet') syndrome. Am J Med Genet 1987;27:773-80.

53 Kaplan LC, Wharton R, Elias E, Mandell F, Donlon T, Latt SA. Clinical heterogeneity associated with deletions in the long 
arm of chromosome 15: report of three new cases and their possible genetic significance. Am J Med Genet 1987:28:45-53.

53:Magenis RE, Brown MG, Lacy DA, Budden S, LaFranchi S. Is Angelman syndrome an alternative result of $\operatorname{del}(15)(\mathrm{q} 1 \mathrm{lq} 13)$ ? Am J Med Genet 1987;28:829-38.

${ }^{54}$ Pembrey M. Fennell SJ, van den Berghe J, et al. The association of Angelman syndrome and deletions within 15q11-13. J Med Genet 1988:25:274A.

55 Lejeune J, Lafourcade J, Berger R, et al. Le phénotype (Dr). Etude de trois cas de chromosome D en anneau. Ann Genel (Paris) 1968:11:79-87.

56 Francke U, Kung F. Sporadic bilateral retinoblastoma and 13qchromosomal delction. Med Pediatr Oncol 1976:2:379-85.

57 Cavenec WK, Dryja TP. Phillips RA, et al. Expression of recessive alleles by chromosomal mechanisms in retinoblastoma. Nature 1983;305:779-84.

5* Benedict WF, Murphrec AL, Banerjec A, Spina CA. Sparkes MC, Sparkes RS. Patient with 13 chromosome delction: evidence that the retinoblastoma gene is a recessive cancer gene. Science 1983:219:973-5.

59 Dryja TP, Cavenec E. White R, et al. Homozygosity of chromosome 13 in retinoblastoma. $N$ Engl J Med 1984;310: $550-3$.

(x) Murphree AL. Benedict WF. Retinoblastoma: clues to human oncogenesis. Science 1984;223:1028-33.

(1) Kougos A. Hansen MF, Lampkin BC, et al. Loss of alleles at loci on human chromosome 11 during genesis of Wilms' tumour. Nature 1984:309:170-2.

62 Orkin AH, Goldman DS, Sallan SE. Development of homozygosity for chromosome $11 \mathrm{p}$ markers in Wilms' tumour. Nature 1984:309:172-4.

${ }^{6.3}$ Fearon ER, Vogelstein B, Feinberg AP. Somatic deletion and duplication of genes on chromosome 11 in Wilms' tumour. Nature 1984:309:176-8.

on Hansen MF, Koufos A. Gallic BL, et al. Osteosarcoma and retinoblastoma: a shared chromosomal mechanism revealing recessive predisposition. Proc Natl Acad Sci USA 1985;82: 6216-20.

${ }^{6.5}$ Friend SH. Bernards R, Rogelj S, et al. A human DNA segment with propertics of the gene that predisposes to retinoblastoma and ostcosarcoma. Nature 1986:323:643-6.

(6) Lee WH, Bookstein R. Hong F. Young LJ. Shew JY, Lee EYHP. Human retinoblastoma susceptibility gene: cloning. identification, and sequence. Science 1987;235:1399.

${ }^{67}$ Fung YK, Murphree AL. T'Ang A, Qian J, Hinrichs SH, Benedict WF. Structural evidence for the authenticity of the human retinoblastoma gene. Science 1987:236:1657-61.

(2) Bartley JA, Patil S, Davenport S, Goldstein D. Pickens J. Duchenne muscular dystrophy, glycerol kinase deficiency, and adrenal insufficiency associated with $\mathrm{Xp} 21$ interstitial deletion. J Pediatr 1986;108:189-92.

(1) Clarke A. Roberts SH, Thomas NST, Whitfield A, Williams J, Harper PS. Duchenne muscular dystrophy with adrenal insufficiency and glycerol kinase deficiency: high resolution cytogenetic analysis with molecular. biochemical, and clinical studics. J Med Genet 1986;23:501-8.

70 Dunger DB. Davies KE. Pembrey M. et al. Deletion of the X chromosome detected by direct DNA analysis in one of two unrelated boys with glycerol kinase deficiency, adrenal hypoplasia, and Duchenne muscular dystrophy. Lancet 1986;i:585-7.

71 Wilcox DE. Cooke A. Colgan J. et al. Duchenne muscular dystrophy duc to familial Xp21 deletion detectable by DNA analysis and flow cytometry. Hum Genet 1986:73:175-80.

72 Hodgson SV, Robertson ME, Fear CN, et al. Prenatal diagnosis of X-linked choroideremia with mental retardation, associated with a cytologically detectable X-chromosome deletion. Hum Genet 1987:75:286-90.

${ }^{73}$ Nussbaum RL. Lesko JG, Lewis RA. Ledbetter SA. Ledbetter $\mathrm{DH}$. Isolation of anonymous DNA sequences from within a submicroscopic $X$ chromosomal deletion in a patient with choroideremia, deafness, and mental retardation. Proc Natl Acad Sci USA 1987;84:6521-5.

${ }^{74}$ Ropers HH, Zuffardi O. Bianchi E, Tiepolo L. Agenesis of the corpus callosum, ocular and skeletal anomalies (X-linked dominant Aicardi syndrome) in a girl with balanced $\mathrm{X} / 3$ translocation. Hum Genet 1982:61:364-8.

75 Gerald PS, Brown JA. Report of the committee on the genetic $\mathbb{Q}$ constitution of the $\mathrm{X}$ chromosome. Cytogenet Cell Genet 1974;13:29-34.

76 Bawle E. Tyrkus M Liman S, Bozimowski D. Aarsk syndrome: full male and female expression associated with an X- .O autosome translocation. Am J Med Genet 1984;17:595-602.

77 Hodgson SV. Neville B, Jones RWA, Fear C, Bobrow M. Two cases of $\mathrm{X} /$ autosome translocation in females with incontinentia pigmenti. Hum Genet 1985:71:231-4.

78 Kapur S. Higgins JV. Delp K. Rogers B. Menkes syndrome in a girl with X-autosome translocation. Am J Med Genet 1987:26: N 503-10.

79 Mossman J, Blunt S. Jones EE. Pembrey M. Hunter's disease in a girl: association with $\mathrm{X}: 5$ chromosomal translocation disrupt- of ing the Hunter gene. Arch Dis Child 1983:58:911-5.

*) Hodgson SV. Heckmatt JZ. Hughes E. Crolla JA. Dubowitz V, 을 Bobrow M. A balanced de novo X/autosome translocation in a girl with manifestations of Lowe syndrome. Am J Med Genet 1986:23:837-47.

*1 Dubowitz V. X;autosome translocations in females with Duchenne or Becker muscular dystrophy. Nature 1986;322: 291-2.

*2 Boyd Y, Buckle V, Holt S, Munro E, Hunter D, Craig I. Muscular dystrophy in girls with $\mathrm{X}$;autosome translocations. $J$ Med Genet 1986;23:484-90.

.3 Ohba N. Yamashita T. Primary vitrcoretinal dysplasia resembling Norrie's disease in a femalc: association with $\mathrm{X}$-autosome chromosomal translocation. Br J Ophthalmol 1986;70:64-71.

st Zuffardi O, Fraccaro M. Gene mapping and serendipity. The $\varrho$ locus for torticollis, kcloids, cryptorchidism and renal dysplasia (31430, McKusick) is at Xq28, distal to the G6PD locus. Hum Genet 1982:62:280-1.

${ }^{55}$ Koenig M, Hoffman EP. Monaco AP. Feener C, Kunkel LM. Complete cloning of the Duchenne muscular dystrophy (DMD) cDNA and preliminary genomic organization of the DMD gene in normal and affected individuals. Cell 1987:50:509-15.

so Simola KOJ, Knuutila S, Kaitila I, Pirkola A, Pohja P. Familial aniridia and translocation $\mathrm{t}(4: 11)(\mathrm{q} 22: \mathrm{p} 13)$ without Wilms tumor. Hum Genet 1983:63:158-61.

87 Moore JW. Hyman S, Antonarakis SE, Mules EH. Thomas GH. Familial isolated aniridia associated with a translocation 3 involving chromosomes 11 and $22 \mathrm{t}(11 ; 22)(\mathrm{p} 13: \mathrm{q} 12 \cdot 2)$. Hum Genet 1986:72:297-302.

\&s Tommerup N, Niclsen F. A familial reciprocal translocation $D$ $\mathrm{t}(3 ; 7)(\mathrm{p} 21 \cdot 1: \mathrm{p} 13)$ associated with the Greig polysyndactyly- 음 craniofacial anomalics syndrome. Am J Med Genet 1983;16: 313-21.

89 Pelz L. Krüger G, Götz J. The Greig cephalopolysyndactyly syndrome. Helv Paediatr Acta 1986:41:381-2.

*) Ventruto V. Pisciotta R. Renda S, et al. Multiple skeletal N familial abnormalities associated with balanced reciprocal trans- $O$ location 2;8(q32;p13). Am J Med Genet 1983;16:589-94.

"' Neri G, Bertini E, Serra A, et al. Myotonic dystrophy ande chromosome translocation segregating in the same family. $J \stackrel{\odot}{\mathcal{D}}$ Neurogenet 1987:4:47-56.

92 Froster-Iskenius U, Hayden MR, Wang HS, et al. A family with Huntington disease and reciprocal translocation 4:5. Am J Hum Genet 1986:38:759-67.

Correspondence and requests for reprints to Profes- $\frac{}{\mathbb{D}}$ sor A Schinzel, Institute of Medical Genetics, $\frac{\varrho}{\sigma}$ University of Zürich, Raemistrasse 74, CH-8001 Zürich, Switzerland. 